\title{
AN APPLICATION OF DOCTRINE OF NECESSITY: PREVIOUS CONSTITUENT ASSEMBLY OF NEPAL AND ITS TIME EXTENSION TO AVOID CONSTITUTIONAL UNCERTAINTY
}

\author{
Vijay Pd. Jayshwal* \\ Department of Constitutional Law, Kathmandu School of Law, Dadhikot 09 \\ Purbanchal University-44811, Bhakatpur, New Thimi, Kathmandu, Nepal
}

\section{Abstract}

This paper aims to investigate issues in relation of constitutional doctrine which had potential debate among the jurists of Nepal for the issues of time extension. The paper will also argue some weaknesses in the constituent assembly and their role expected by the people of Nepal. This paper will discuss about the evolution of constitution in Nepal, its features, the principle of Constitutionalism embodied in Nepalese constitution. This paper will further argue about the legitimacy of Doctrine of Necessity and its application in Nepal. In last, this paper will show the possibility of constitutional uncertainty by newly elected constituent assembly.

Keywords: constituent assembly, constitutional uncertainty, constitution.

\section{Intisari}

Penulisan ini dalam rangka mengkaji doktrin konstitusional yang tengah ramai diperdebatkan oleh para ahli hukum di Nepal, khususnya berkaitan dengan isu mengenai perpanjangan waktu. Melalui tulisan ini, terdapat temuan yang menunjukkan beberapa kelemahan yang ada dalam majelis konstituate Nepal di samping peran-perannya sebagaimana yang diharapkan oleh rakyat Nepal. Tulisan ini membahas pula mengenai evolusi konstitusi Nepal sebagaimana diwujudkan dalam prinsip-prinsip konstitusionalism yang dianut oleh Konstitusi Nepal. Lebih lanjut, berkaitan dengan legitimasi dari Doctrin of Necessity dan penerapannya di Nepal. Pada akhirnya, tulisan ini akan memberikan gambaran mengenai kemungkinan ketidakpastian secara konstitusional berkaitan dengan kondisi majelis konstituante yang baru saja terpilih.

Kata Kunci: majelis konstituante, ketidakpastian konstitusional, konstitusi.

\section{Pokok Muatan}

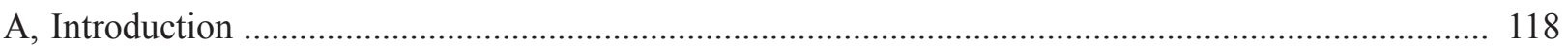

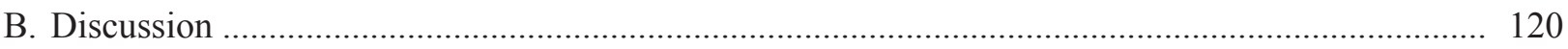

1. Features of Constitutionalism and legacy of Constituent Assembly of Nepal ........................... 120

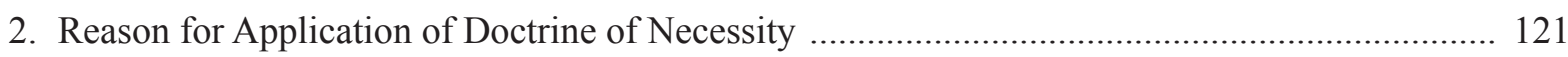

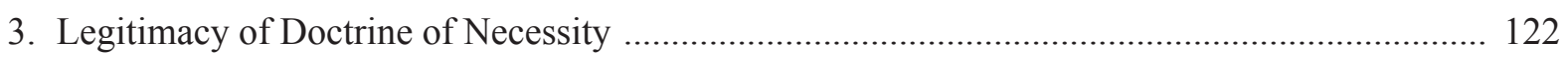

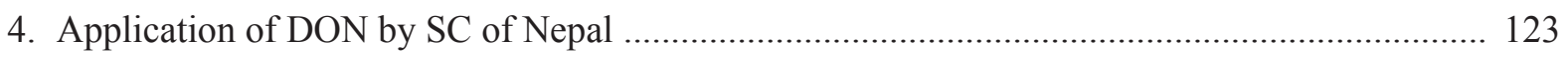

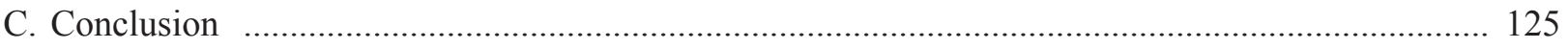




\section{A. Introduction}

The word constitution is generally used within a given country to mean the supreme law of the land, a frame work for government and legitimate vehicles for granting and limiting the power of the government officials. Constitution of a nation apart from being fundamental law of the land also carries high degree of sociopolitical recognition that forms the basis of its implementation, interpretation and crucially more than just legalistic assertion of legitimacy, such recognition permeates the constitution with high degree of moral authority. Indeed constitution is more than a mere text. It transcends beyond its letters and words "broad philosophical value" that gives normative and factual relevance to the text of the constitution. ${ }^{1}$ While constitutionalism reflects wide normative ideas of a democratic constitution such as, parliamentary hearing, supremacy of law, rule of law, human rights, limitation over government authority, judicial review, and independent of judiciary and responsible government. ${ }^{2}$

According to a widely accepted political theory typically associated with constitutionalism, a constitution is understood to be a document deliberately created by a society for its own self-governance which expresses that society's fundamental desires about how it ought to live. Because on this view a constitution is a kind of charter for living, it therefore necessarily reflects the beliefs of the people who make it about the nature of a good life, both for the self-governing community that the constitution directly governs, and for the individuals who inhabit it. A second aspect of constitutionalism, highly prominent in the American branch of the tradition, refers even more particularly to the belief that a paramount goal of collective self-governance is the protection of liberty, and that a critically important function of any constitution. ${ }^{3}$

Nepal lacked what we could call a constitutional document before 1948 because for the first time in the history its geographical unification had made possible. Dharmasastras (Religious Text) was exclusive agreed sacred text and was the governing principles of dharma (righteous conduct) referred to the privileges, duties, and obligations of human beings, his standard of conduct towards almighty, to society, and to himself/herself, and served as the moral standard against which all religious, political, or social actions were to be tested. It was continued in practice since the rudimentary form of governance was introduced in the country.

Jung Bahadur Rana was autocrat but also helped to promulgate the National Civil Code of 1854, which codified the existing customary laws, introduced the necessary rules for governance, and placed all the ruling class, as well as commoners, under the umbrella of an explicitly codified law. The underlining principle of constitutionalism is limited concept of government that Nepal had was undermined when the kings were sidelined and state power was taken over by the Ranas. Nepal has had six constitutions: the Constitutions of 1948, 1951, 1959, 1962, and 1990, and the Interim Constitution of 2007. These all constitution was introduced in different course of development in the governance system of Nepal. Some constitution was introduced under the strict guidance of Monarchy while some was under the authoritarian regime. The latest constitution was the turning step from Monarchy to Republic and was introduced under the will of sovereign people of this country. This Interim Constitution had ended the historical legacy of Monarchy which was ruling since 240 years in country and there was ample condition in this period when people were exempted from the basic

Larry Alexander, 2000, Practical Reason and Statutory Interpretation, collected Essays in Law, Legal Rules and Legal Reasoning, Dartmouth Publishing Company Limited, London, pp. 319-322.

A.V. Dicey, 1915, Introduction to the Study of the Laws of the Constitution, 8th Edition, Palgrave Macmillan, London, pp. 107-122.

James A. Gardner, "In Search of Subnational Constitutionalism", Paper, Seventh World Congress: International Association of Constitutional Law Athens, State University of New York University at Buffalo Law School, Greece, June 11-15, 2007. 
liberties, freedom, and human rights.

Democracy and upcoming Constitution has the interconnection. Basically there are three questions which are arising in relation of democracy in Nepal. First one, rethinking about democracy which talks about the old system has failed to respond the public voice so we have to search the new form of system. Second is future of democracy which advocates protection and promotion with inclusion of preservation of social justice. Therefore, their one is like thinking of democracy which talks about the coalition government formation. These all three concepts only clarify the shape of the constitution. Inside the constitution, there must be the protective mechanism. Because in present scenario, Nepalese peoples have fully understood the game of politicians, they are not in position to trust the any politicians. We want the constitution itself have devices to supervise the politicians. Participation of people should not only take place every five years during the elections, but should be a continuous process.

In KeshavanandaBharati v. State of Kerala the SC has interpreted and gave wider definition of constitution far from the political spectrum. A constitution can't be regarded as mere legal document to be read as a will or an agreement not is constitution like a plant or a written vehicle of the life of the nations ${ }^{5}$. Every constitution is constantly undergoing changes of various kinds through the impact of new needs upon it. But the means by which changes take place differ greatly. Necessity for alternations in the institutional structure of government arises under all systems. ${ }^{6}$ The word constitution is ambiguous. It has two senses which are most often mixed up. Constitution is being meaning either a compact written document, comprising paragraphs with rules for the government of the state, or constitution standing for the regime. ${ }^{7}$ Some of the constitution may be called as rigid where as some others are flexible on the basis of amendment procedure. A rigid constitution is one which does not make its amendment simple and easy.

Traditionally, constitutionalism is a legitimating to the power of the key actors and state. Constitutionalism provides fundamental or basic scheme of a state or government. In other words, it is a broader framework under which the different actors accept, respect, and practice the limitations set by the framework. The framework composes the form or structure of the state. The limitation are the central elements for constitutionalism, when the limitations are ignored, constitutionalism will be enfeebled and when the limitation are violated, it would be shattered. In short, constitutionalism is the Grundnorm (Kelsenian Doctrine) of a constitution on which lies the foundation of the constitution. ${ }^{8}$

The novelty of constitutionalism is often epitomized as an establishment of a genuine law- giving government, capable of maintain the stability and order, necessary to realize the purposes of community, defined and structures as to prevent tyranny. Modern constitutionalism incorporates both ideas: the limitation of the government as well as the expansion of the rights of the people. ${ }^{9}$ Constitutions are intended tp preserve practical and substantial rights not to maintain theories. In a democratic country, the constitution guarantees certain basic rights and liberties to the people while criminal justice administration stood as protector of the rights. ${ }^{10}$ Constitutionalism is the heart of the constitution. It produces the legitimacy and legacy of the constitution. In absence of constitutionalism, no country can claim to have good constitution. It protects the rights or people through preventing the bad action of the government. It helps to realize and

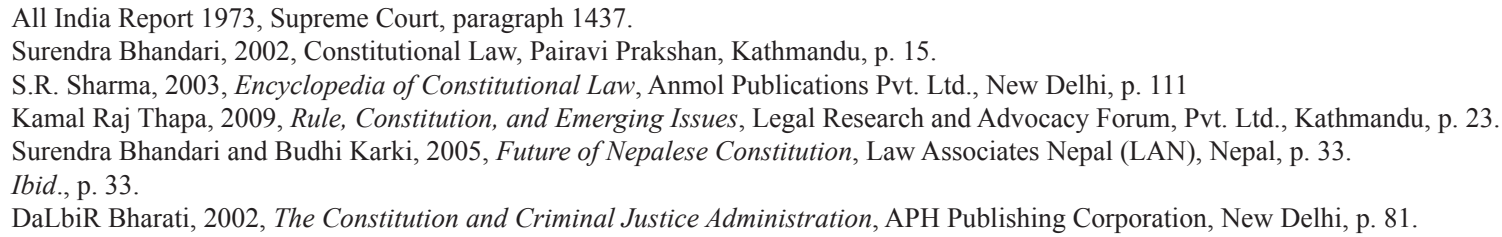


utilize the rights secured by the constitution.

\section{B. Discussion \\ 1. Features of Constitutionalism and Legacy of Constituent Assembly of Nepal}

Although the term "constitutionalism" has many meanings, it is unnecessary for present purposes to distinguish finely among them because they all point more or less toward the same general idea, one well captured in U.S. Chief Justice John Marshall's famous dictum, issued nearly two centuries ago: "we must never forget that it is a constitution we are expounding." Constitutionalism is to create demarcation line with between the political issues and legal issues. In definition what questions are political are most be defined by the court. In famous case of USA regarding the Federal and Central government in issue of political question has made beautiful description under principle of constitutionalism, Baller v Carr (1962) ${ }^{12}$ provided criteria reflecting classic, functional and prudential considerations.

Classic doctrine, if the issue has been committed by the constitution to the discretion of another government decision maker, federal courts will treat it as a political question. But whether the issue is constitutionally committed to a particular branch is itself a judicial question. ${ }^{13}$

Functional Considerations, a question may be labeled, "political" because the court determines that the judicial branch lacks the resources and capabilities for resolving it. For example, a lack of judicially discoverable and manageable standards for resolving the question like, foreign affairs issues may render the question of political. ${ }^{14}$

Prudential Consideration, constitutional issues may also be labeled political because of prudential or policy considerations relating to the power use of the judicial power. ${ }^{15}$ If process is constitutionally valued, therefore is must be valued not only as a means to some independent end. But for its intrinsic characteristics, being heard is part of what is means to be person. ${ }^{16}$

Some remarkable feature of constitutionalism is democracy, separation of power \& Check and Balance, guarantee of civil, political, economic, social and cultural rights, independent of judiciary $\&$ its accountability, rule of law and supremacy of law.

The CA was to consist of 205 members elected on single member geographical constituencies and 204 elected on party lists (on the basis of proportionality). The only provision for the candidates for elections, those parties shall take into consideration the principle of proportional representation. The third category consists of 16 members appointed by the government on the basis of consensus form among prominent persons of national life. The election took place in 2063 where diverse Nepalese society get chance to elect their representative for the CA. The CA broke the formally legacy of Monarchy and it based constitution of 1990. The people again become able to put their voice under the common platform on the same level of standing in comparison of others. The IC was first legal document to replace the legitimacy of 1990's constitution which was made by the ne elected CA member. The tenure of CA was for two years form the first date of CA members meeting as per article 64 of IC.

The CA is legitimate body for the draft of constitution. It is the body comprising of elected member by the people and some professional experts. The CA as per the mandate set by the IC will continue to work for the two years as per Article 64 of IC.

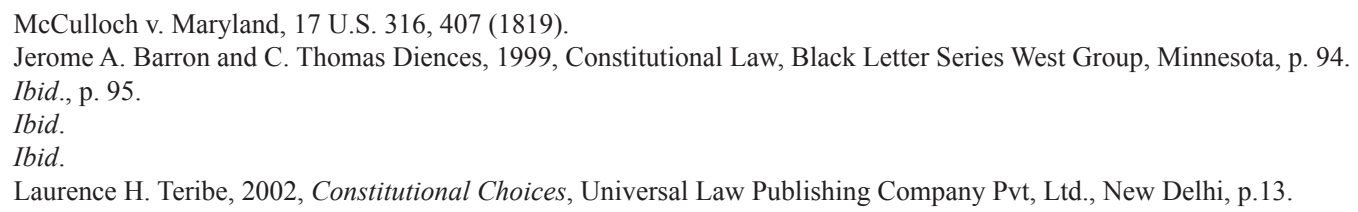




\section{Reason for Application of Doctrine of Necessity}

There were number of argument floating in the ambit of Nepal Bar Association and Judiciary of Nepal about the reason for application of doctrine of Necessity. The Supreme Court had not quashed the ninth amendment of the Interim Constitution of Nepal, which had extended the tenure of the Constituent Assembly (CA) by three more months on May 28. This was the first reason for the application. The Supreme Court has considered the possibility of giving constitution within the time framework.

The bench quashed the petition filed by advocate Balkrishna Neupane and Hindu activist Bharat Jangum seeking that the ninth amendment of the Constitution be quashed. The bench stated that there were was no need to change May 25 verdict that interpreted Article 64, stating that the CA term cannot be extended more than 6 months of its original tenure, which it was supposed to do in a state of emergency or as per the doctrine of necessity. ${ }^{17}$

The five-member special bench presided by Chief Justice Khil Raj Regmi, Justices Top Bahadur Magar, Damodar Prasad Sharma, Ram Kumar Prasad Shah and Kalyan Shrestha issued the judgment. Stating that it could not issue the text of judgment is due to lack of time. Today's verdict is intended to pave a way out of the present crisis and give one more chance to the Constituent Assembly to complete its main task of constitution writing. The bench is still stuck to its previous interpretation of CA's original two-year tenure and issued the verdict as expected, following the formation of the bench to look at various settled issues.

The former President of Nepal Bar Association had told that the time has asked for the application of this doctrine. There are no any remaining ways out to keep alive the Constituent Assembly. The CA members are working hard and they are in hope of giving constitution within the extended time frame.
Senior advocate Bishwokanta Mainali, who had pleaded on behalf of the government, termed the verdict 'timely relative' and 'wise decision' of the apex court. "The apex court indirectly changed its previous interpretation and passed the verdict in favor of the people and the nation," Mainali said adding, "Since it was a historic issue, the apex court it reviewed in wisely."

The dissimilar opinion has seen with the senior advocate Devendra Nepali Shrestha, who pleaded on behalf of the writ petitioners, stated that though the bench quashed the petition it did not uphold the CA tenure extension. "The bench is glued to its earlier verdict." He has spoken not in favor of time extension and application of doctrine of necessity.

Attorney General Dr Yuba Raj Sangroula interpreted the verdict in favour of the Constituent Assembly and the government for upholding the CA extension for a few more months to complete the constitution writing and peace process. "The verdict has overruled its previous one and issued liberal interpretation as per reasonable expectation. Dr. Sangroula has pleaded on side of government stating that $\mathrm{CA}$ is for the constitution drafting body. This is not ordinary time where the non draft leads to dissolution. There are number of issues which if the Constitution failed to incorporate shall invite further chaos and conflict in the society.

There are some seen reasons for the application of this doctrine: First, is that if we look in the past, the doctrine of necessity has made legitimate to the action otherwise it wouldn't be. It has said that this doctrine applied when all the remaining doors are close or there are no means to resolve the conflicts. The CA of Nepal was doing its best and working to draft the constitution within the time given by the Interim Constitution. The CA had faced number of political turmoil and up down which proven CA not able to draft. The CA was suspended and stopped to work by the political parties time and again. There were massive internal 
and external disturbances inside the CA and outside CA which badly dragged.

Second, for application of this doctrine is to keep alive considers the work of member of CA. The member of CA was able to come up with their final draft from the respective committee and almost 80 $\%$ of work was done. There were major three issues which were appearing as the differences among the political parties. The federal structure, the basis for federalism and the forms of government were pulling back to all political legs. SC has applied to save the voice of people.

Third, for application is the notion of perception of constitution. Constitution is not only a legal document but also a political, social, economical testament and vision of a nation. Constitution embodies the hope and aspiration of the people of many generations and expected to be so in the time period yet to come. Therefore, CA, which has received the mandate from the people, will be exercising its power in various capacities and its functioning are not merely discharge of legal and constitutional functions. It is not only the implications of the outcome is political but the role of CA is itself is different from parliament under democratic set up. As the 'doctrine of necessity' comes with enormous peril of being misused and susceptible to tampering in future, it would be difficult for courts to stay away from the controversy inasmuch as the present verdict could be taken as stamping on the power of CA to extend its term, sometimes based on its own sweet will and fancy.

\section{Legitimacy of Doctrine of Necessity}

Constitution always favors people's aspiration

if it embodies democratic principles. Nepal's constitutional history had tress passed number of regime and incorporated democratic principle and values in accordance with time and necessity. The doctrine of necessity applied by then CA was also in order to prevent the constitutional uncertainty and constitutional vacuum in Nepal. There were some features since 1948 in the constitutional history in Nepal. As first, constitution defines ite nature, specify the forms and structure of the government, distribute the power between the different organs of the government and the constitutional bodeis. ${ }^{18}$

If we see how the doctrine of legitimacy got legitimate in Nepal then we can't forget the failure of Nepal's previous constitution. Nepal doesn't have coherent experiences ever since it got the first constitution in 1948. Out of five and the recent Interim Constitutions enacted hitherto in Nepal none of them have provided sound and coherent constitutions. A handful of individual have played a key role in the constitution making process throughout the actual aspirations of the people. ${ }^{19}$ This failure had given again the legitimacy of doctrine in Nepal applied outside countries.

Although Black's Law Dictionary, eighth edition did not say anything about the doctrine of necessity rather it defines necessity as a legal principle which is a "justification for a person who acts in an emergency that he or she did not create."The term, Doctrine of Necessity, was first used in 1954, in Pakistan when the Pakistani Chief Judge, Muhammad Munir, validated use of emergency powers by Governor General, Ghulam Mohammad. In his judgment the Chief Justice cited Bracton's maxim, "That which is otherwise not lawful is made lawful by necessity", thereby providing the label that would come to be attached to the judgment and the doctrine that it was establishing. The Doctrine of Necessity was also invoked in 1985 in Grenada for the second time to permit a murder trial to continue in courts that had been brought into being by an extra-constitutional decree. The doctrine was used for the third time in Nigeria on February 9, 2010 when the National Assembly passed a resolution making the Vice President, Goodluck Jonathan the Acting President 
and Commander in Chief of the Armed Forces. Furthermore, this doctrine was used by the SC of Nepal to extend the time frame of IC through their verdict. Constituent Assembly Dialogue team on the recent decision of the Supreme Court on the validity of the Interim Constitution (Ninth Amendment) Bill 2011. Citing the doctrine of necessity, the Supreme Court in this case declined to quash the controversial amendment bill on the ground of unconstitutionality, thereby permitting the extension of the tenure of the Constituent Assembly (CA) by three more months on May 28, 2011.

\section{Application of DON by SC of Nepal}

Article 64 of the Interim Constitution clearly mentioned the time frame of the CA from first meeting of its member. It clearly states that unless and until CA will otherwise dissolved earlier by the Constituent Assembly (CA) itself, the term of the house shall be two years. This rule is not out of the exception. The term of the house may be extended for up to six months in the event that the task of drafting the constitution is not complete due to the proclamation of a state of emergency in the country.

When the constitutionality of the eighth amendment bill was challenged last year, the court agreed that there could be no extension beyond six month, whether there is emergency or any other dire necessity. But it declined to declare the unconstitutional extension null and void at that time because it thought that would negatively affect the achievements of the CA made during this extended period. But the judgment of the court left little space for the CA to work on another extension after the completion of this unconstitutionally acquired one year additional term.

However, on 29 May the verdict was disobeyed and CA term extended for three more months. During the ninth amendment of the CA, the day when Maoist leader Baburam Bhattarai became Prime Minister, there was no such provision as to extend the term of CA again. There had been a writ petition against extension of CA term, but the Supreme Court (SC) citing the 'Doctrine of necessity' gave its delayed verdict at $6 \mathrm{pm}$ in favour of extension. The term will expire on 30 November. The SC's 'Doctrine of necessity' is only for three months; and for once only. However, if that 'Doctrine of necessity' is time and again repeated on court's backing then there will be no constitutional value in national and international community. The verdict of the SC was laden with defect and this 'Doctrine of necessity' was implemented in a constitutional crisis. There is a debate ongoing at the SC that the 'Doctrine of necessity' should not be repeated. The debate continues at SC that the extension is unconstitutional.

The 'Doctrine of necessity' may once be implemented but cannot be so every time. In the developed countries of the world such a doctrine has never been tried. In the United States of America such policy has not been given any recognition. In 1954, the policy was practiced in a developing and unsuccessful nation as Pakistan. Sometimes, somewhere for once can constitutional values be disregarded or violated to implement such ideologies.

We have to cogitate deeply- Will murder, terror, robbery and corruption stop in name of peace and constitution? Maoists killed more than 15,000 common Nepali citizens, military and police, and thousands kidnapped while many families had to be relocated. Some even flew abroad to save themselves during the decade-long Maoist conflict in Nepal. While the families of the deceased are still mourning; the families of the kidnapped and disappeared are still searching for their loved ones. Nepal now is governed by those who once were involved in the conflict. It is a serious question to the Maoists who are in the regime. Will impunity prevail forever in Nepal? Are there any other places where victims can go and appeal for justice?

In the $10^{\text {th }}$ amendment of the IC, the following arguments are presented by the SC of Nepal:

Advocate, Bharat Mani Jangham \& BalkrishanaNeupane V Office of President and others (068-WS-0014), 2068 (2011A.D.) B.S. Constitutional issues: $10^{\text {th }}$ amendment of the Interim Constitution of Nepal must be declared 
null and void.

\section{a. Petitioner Argument}

The 1oth amendment of the Interim Constitution (IC) is against the norms and values of the constitution so as per the $\operatorname{article}^{20} 32$ and article 21107 (1) and (2) must be declared null and void. Article 64 of the IC has mentioned the time period of the Constitution Assembly (CA) which is 2 years from the date of the first meeting of the constituent members. In the time of emergency, the dead line of the Constitution Assembly can be extended only up to 6 months on the basis of doctrine of necessity. The $8^{\text {th }}$ and $9^{\text {th }}$ amendment of the IC is not declared unconstitutional but it is also not legalize the process by the court. Article ${ }^{22}$ 148 has already incorporated the provision of the amendment of the constitution. It is against the preamble of the IC, $\operatorname{article}^{23} 2,13$, $32,63,64,83,85$, and 148 . So that, it must be declared void.

\section{b. Defendant Argument}

The constitutional and legal question regarding the amendment of the IC has already interpreted by the court in the previous $8^{\text {th }}$ and $9^{\text {th }}$ amendment. So that there is no any rational of bringing the writ again for the same cause of action. Supreme Court has already given the legitimacy of $8^{\text {th }}$ and $9^{\text {th }}$ amendment of the constitution as per the doctrine of Necessity. $8^{\text {th }}$ amendment of IC extended the time period the IC by 1 year and between these period the CA has done a lot of works and able to resolve number of differences among the parties and issues. $10^{\text {th }}$ amendment extended the time period of the IC by 3 months. The
CA will defiantly full fill the aspiration of the Nepalese peoples and draft constitution. The IC, 2063 has motto to draft new constitution from the elected constitution assembly. Until the constitution will not draft, the CA have mandate to work Article 64 has the provision of the time period of the CA but in mean time article 82 has mentioned, the responsibility of the CA will be ended when the IC will made. Article 148(1) has incorporated the any provision of the constitution can be amended throughout the bill presenting in the parliament by $2 / 3^{\text {rd }}$ majority. So that article 64 can't be called as Non-amendable article. Necessitasfacitlicitumquodm alias non estlicitum, necessity makes that lawful which otherwise would not be lawful is the established doctrine under the jurisprudence of the constitutional law. Article 87 of the IC said, any bill passed by the parliament and authenticated by the head of the president shall be consider the Act, Law. The $10^{\text {th }}$ amendment of the IC has also fulfilled the same process. So it has the constitutional legitimacy. Madhav Kumar Basnet ( Amicus Curie) had said, the supreme court must preserve the continuity of the constitution in time of its interpretation. As per Article 166(2), the daily politics is constitutional so that this provision must be interpreted in the others manner.

\section{c. Court Decision}

Court has defined the doctrine of necessity, "a situation when a person or group are not in condition to full fill the responsibility ( Kabu BhairkoSthithi), the issues can be excused "Extra legal decision

20 Right to Constitutional Remedy, the right ti proceeds in the manner set out in Article 107 for the enforcement of the rights conferred in this part is guaranteed.

21 Jurisdiction of the Supreme Court, Interim Constitution (2063 B.S.), Nepal, p. 164.

22 Amendment of the Constitution, A Bill regarding amendment or repeal of any Article of the constitution may be presented in the LegislatureParliament $(148,1)$ and the Bill shall be deemed passed if the Bill so presented at the Legislature Parliament is approved by at least two-thirds majority of the total existing member (2), p. 234.

23 Sovereignty and State authority(2), Right to equality (13), Right to Constitutional Remedy (32),Formation of the Constituent Assembly (63), terms of the constituent Assembly (64), Acting in the capacity of Legislature-Parliament (83), Procedure for passage of Bills (85). 
also can be legal by applying the doctrine of necessity. Necessities defends and justify what it compels, it is the law of time and the place.But on the same issues, if you apply the doctrine of necessity frequently then it would not be reasonable. Constitution assembly has mandate to draft the new constitution and change the aspiration of peoples into reality. The CA has duly assigned with its duty and responsibility expected to be performed. The $10^{\text {th }}$ amendment of the IC is reasonable and CA would draft the constitution in the extended time period. So that in days also there can be time extension more. Writ is dismissed hereby.

\section{Conclusion}

The Doctrine of necessity has applied globally when time requires. Such as, in countries like Nigeria and in Fiji, doctrine were invoked and applied whenever the state had acted against the constitution. There were striking similarities in all these states at the time when the doctrine was invoked - dysfunctional parliamentary democracy. The democracy of Nepal was also not in functional during the constitution draft period. All the political parties were in rush for forming the government and busy with the ministries only. This gave futile land for the application of this doctrine. The history had shown the same instances. This will inevitably leads us to the question - whether doctrine of necessity is a necessary doctrine when there is a breakdown of parliamentary democracy.

The SC is regarded as the guardian of the fundamental rights in case of violation of it. The IC of Nepal mandated two years of CA from the date of first meeting of the CA members. The exceptional clause to this is under the article 64 sub article. The politico-legal scenario of the Nepal is totally different than the country where the doctrines of necessity are applied. The legal and political questions are still on the pipe line of the judiciary action. The judiciary has shown their power by giving legitimacy of the time extension bill of the $10^{\text {th }}$ amendment. The issues of time frame is neither pure legal not pure political because in case elected parliamentarian try to become the tyranny and dictators, it is the judiciary who has responsibility to check them is the words of some critics of verdict of $\mathrm{SC}$. The CA is made under the due consideration to draft the new constitution which can reflect the sovereignty of people. The historical injustices were also supposed to compensate by making the constitution through giving the life in the principle of recognition of entitlements of rights

There were number of intellectuals who were arguing about the limitation over the doctrine of necessity. The immediate question which caught attention of everyone was that how long the doctrine of necessity can save the functioning of CA or any such extra - legal actions of state actors in the future. Dealing with the issue vis $-\mathrm{a}-$ vis functioning of CA, what if, the CA fails to perform its functioning of promulgation of new constitution but based on this doctrine; it keeps on extending its term for another dozen times. By adopting this doctrine by highest judiciary of the country, we have placed ourselves in a very precarious situation where CA may not function as per the mandate given by people and the constitution but whatever it does going outside the Constitution would be held constitutional. Then, what incentives CA members would have even to be serious for constitution making when their terms and tenures are guaranteed by 'doctrine of necessity'.

This was trying to deliver that continue application of doctrine will bring constitutional uncertainty in Nepal. The political parties were busy to play with their own game of power politics and no one will care about the constitutional writing process. The doctrine has also erased hope among the people that $\mathrm{CA}$ will deliver the constitution within the time.

There are two basic structure of the constitution. Can CA or Parliament amend all provision of constitution or not was serious question during the post colony era in the South Asia. The Nepal Interim Constitution under its amendment 
framework entitled to be amended by the CA but this power is limited also. There would be some argument to say that the doctrine of necessity alone cannot extend the tenure of CA for more than six months. However, the so called sovereign CA has all the incentives to amend the provisions in Interim Constitution and remove such barriers where if the mighty CA wishes, it can extend its term by innumerable times. The Article 64 of the Constitution seems to be non- amendable provision.

However, if we have to take a positive from the verdicts rendered, a silver lining can be that the court has upheld the supremacy of the parliament/ $\mathrm{CA}$ and this supremacy could have been upheld even without resorting to 'doctrine of necessity'. When there is enormous pessimism on people for not having stable functioning parliamentary democracy with able executive, it can only be hoped that the verdict, though may be founded on uncanny reasoning would be taken as a positive steps towards stable supreme parliament. If people are able to take this positive, another positive hope that comes to our mind naturally would be, hopefully, we will soon see our New Constitution.

The doctrine of necessity and verdict of the Supreme Court (SC) of Nepal is regarding the time extension of Constituent Assembly (CA) tenure. The judicial verdict are not free from the critic although it has try to save the life of the CA just by promulgating progressive decision in favor of the CA time period. The other group of Nepalese jurist have filed writ under the jurisdiction fixed by the article 107 of the Interim Constitution (IC) and argue against the spirit of the decision. At this juncture, the first and foremost issue among the legal experts should be the implications of borrowing such principle into Nepalese Legal System which can have serious ramifications on fundamental points concerning the rule of law and constitution, the retrospective exercise of legislative powers by the law makers, and the yardstick and benchmark to adjudge the legality of actions in the future.

The judiciary are not merely regarded as the protector of rights of people but it sometime help to protect nation from the path of chaos and conflict. The time extension verdict of the SC has done the same things. The doctrines of necessity apply only when the law is silent and there is no any alternative for the parliament and judiciary too. The doctrine of necessity provides the legitimacy of extralegal action of the government.

The SC of Nepal through their progressive decision in side of one sort of jurists also creates state of confusion and lack of clearness. The doctrine of necessity itself has some limitation like the time of its application, environment of it, the process of it and finally the legitimacy to it. The judiciary is overwhelming the political question of time frame and becoming the part of the politics are serious criticism of the scholars of constitutionalism.

Hence, the judiciary has save the life of CA by giving the verdict in favor of $10^{\text {th }}$ extension bill by dismissing the writ. The judiciary has shown their power to make legitimate to the decision of the CA member. But the SC is clear on the ground that the DON can't be apply all the time and also make warning to the CA member to promulgate full flexible constitution. The doctrine itself is not far from the criticism

\section{BIBLIOGRAPHY}

\section{A. Books}

Alexander, Larry, 2000, Practical Reason and Statutory Interpretation, collected Essays in Law, Legal Rules and Legal Reasoning, Dartmouth Publishing Company Limited, London.
Barron, Jerome A. and C. Thomas Diences, 1999, Constitutional Law, Black Letter Series West Group, Minnesota.

Bhandari, Surendra and Budhi Karki, 2005, Future of Nepalese Constitution, Law Associates Nepal (LAN), Nepal. 
Bhandari, Surendra, 2002, Constitutional Law, Pairavi Prakshan, Kathmandu.

Bharati, DaLbiR 2002, The Constitution and Criminal Justice Administration, APH Publishing Corporation, New Delhi.

Dicey, A.V., 1915, Introduction to the Study of the Laws of the Constitution, Palgrave Macmillan, London.

Khanal, Krishna P., 2005, Nepal's Discourse on Constituent Assembly, Friends for Peace, Kathmandu.

Pant, Shastra Datta, 2007, Comparative Constitutions of Nepal, Parivi Prakashan, Kathmandu.

Sharma, S.R., 2003, Encyclopedia of Constitutional Law, Anmol Publications Pvt. Ltd., New Delhi.

Teribe, Laurence H., 2002, Constitutional Choices, Universal Law Publishing Company Pvt, Ltd., New Delhi.

Thapa, Kamal Raj, 2009, Rule, Constitution, and Emerging Issues, Legal Research and Advocacy Forum, Pvt. Ltd., Kathmandu.

\section{B. Paper}

Gardner, James A., "In Search of Subnational Constitutionalism", Paper, Seventh World Congress: International Association of Constitutional Law Athens, State University of New York University at Buffalo Law School, Greece, June 11-15, 2007.

\section{Government Regulation}

All India Report 1973, Supreme Court.

Jurisdiction of the Supreme Court, Interim Constitution (2063 B.S.), Nepal.

\section{Miscellaneous}

McCulloch v. Maryland, 17 U.S. 316, 407 (1819).

The Himalayan Times Doctrine of necessity cited to uphold CA term - Detail News Nepal News Portal.mht. 